\title{
TÓPICOS PARA UMA REFLEXÃO DEMOCRÁTICA EM UMA CIVILIZAÇÃO TROPICAL
}

Thais Florencio de Aguiar

O objetivo deste ensaio é conceber em que medida a reflexão sobre a constituição de uma civilização brasileira legou conteúdos e subsídios para o pensamento sobre democracia nesse território. Para tanto, tomou-se como objetos de pesquisa obras pontuais do Visconde de Uruguai, de Tavares Bastos, Euclides da Cunha, Sérgio Buarque de Holanda e Gilberto Freyre. Mesmo naqueles autores nada identificados com a questão democrática foi possível encontrar formulações úteis a essa questão à medida que pensaram a formação do povo e do governo desse povo. Tentou-se, então, assinalar os corolários de tais formulações para a organização social e a política democrática. Além disso, a própria reflexão sobre a constituição de uma civilização brasileira coincidiu com a experimentação e o pensamento sobre a democracia no cenário político ocidental.

É certo que a teoria democrática avançou no horizonte intelectual europeu e americano somente ao longo do século XX. Entretanto, a democracia, como forma de governo, ganhou contornos na modernidade com o advento das revoluções já nos séculos XVIII e XIX e juntamente com 
tais eventos, constituiu-se um pensamento político sobre a democracia. O mesmo pode ser dito sobre a produção intelectual no Brasil, país que não esteve totalmente alheio à reflexão política em produção nos países ditos "centrais". Embora o pensamento sobre a democracia no Brasil seja relativamente recente, algumas reflexões em torno de uma nova forma de governar, cujo sujeito central era o povo, podem ser deduzidas de esforços teóricos anteriores.

Do Império à República, os pensadores de então articularam antinomias que vieram constituir o pensamento social brasileiro, tais como os dilemas entre tradição e ruptura, a questão da centralização e descentralização ou ainda a primazia do Estado e autonomia da sociedade. Essas antinomias constituíram o legado desses pensadores para a reflexão política e social brasileira e, a partir delas, eles propuseram algumas questões sobre a democracia em uma civilização tropical, como o Brasil.

204 Ao longo desse percurso intelectual, é importante perceber como pensamento político e análise sociológica distinguiram-se em termos de produção de concepções acerca da organização social e política do Brasil. De um lado, a teoria política julgava estar fundamentada em suposto "realismo sociológico". Por outro lado, os estudos de cunho sociológico apontavam a falta de instituições políticas correspondentes à formação social brasileira, sem avançarem no desenvolvimento de proposição de uma forma política. Este artigo atenta, assim, para a precedência da política ou da sociologia no argumento dos autores, um pouco inspirado no que sugere Werneck Vianna, em estudo de $1997^{1}$. Nessa perspectiva, compreender a intrinca-

\footnotetext{
${ }^{1}$ Esse ensaio foi desenvolvido a partir do curso "Leituras sobre Pensamento Social e Político Brasileiro" ministrado em 2007 pelo professor Luiz Werneck Vianna, no Instituto Universitário de Pesquisas do Estado do Rio de Janeiro (Iuperj). Agradeço ao professor Cesar Guimarães, do Iesp, pelos comentários feitos à versão original. Ressalto que possíveis equívocos são de minha inteira responsabilidade.
} 
da relação entre sociologia e política brasileiras pareceu importante para discussão sobre os limites do imaginário político de cada geração, isto é, daquilo que a democracia brasileira poderia vir a ser, segundo a imaginação de cada grupo intelectual.

\section{Acerca de questões para a reflexão democrática}

\section{Tutela da multidão e ensino do self-government}

A construção de uma civilização brasileira, preocupação central dos pensadores políticos pós-independência, foi marcada, segundo a interpretação corrente, por uma vocação territorialista da política. Com efeito, constituir, em território de dimensões continentais, um país formado pelo ajuntamento de três matrizes étnicas foi considerado grande façanha, ainda mais quando se assistia à balcanização em curso na América hispânica. Por esse motivo, a noção de unidade nacional se inscreveu na tarefa de constituição da civilização brasileira, como um valor político absoluto.

Essa tarefa relacionava-se a um dos grandes debates travados na política do Brasil Império, a saber, o da centralização do poder. Foi a experiência da descentralização operada pela Regência, nos anos de 1830, que inaugurou o embate entre o projeto centralizador e o projeto descentralizador. A partir dessa experiência, reforçou-se a convicção sobre a inviabilidade de se forjar uma política nacional com base na formação social. Essa convicção foi professada, entre outros, por Paulino José Soares de Sousa, o Visconde de Uruguai. Para esse pensador, a descentralização inspirada no modelo anglo-americano e experimentada no país teria buscado ampliar o autogoverno em meio a lastro social adverso. A prova cabal de que o país não estava preparado para a descentralização foi a eclosão de revoltas regionais subsequentes à transferência de poder para as assembleias provinciais (Uruguai, 2002). 
Como observa José Murilo de Carvalho (2002), Uruguai acreditava que a descentralização não poderia ter sido instaurada como fora, isto é, pelo simples efeito de legislação. Grande leitor de Alexis de Tocqueville e François Guizot, Uruguai condicionava a política às circunstâncias sociológicas. Nesse sentido, de acordo com ele, faltava aos homens da Regência certo "realismo sociológico", com base no qual poderiam observar, sem dificuldade, que os fatos não favoreciam o empreendimento descentralizador e que este dependia "das circunstâncias do país, da educação, dos hábitos e caráter nacionais e não somente da legislação" (Uruguai, 2002, p. 437). De maneira mais ampla, o fator sociológico, embora central, não era o único que contava para uma boa constituição política, na concepção de Uruguai. Importavam também as condições topográficas, a dispersão da população, as divisões territoriais, o número de homens talentosos dignos de confiança na gerência dos negócios locais e a har206 monia entre interesses econômicos regionais.

Ao se considerar o cânone sociológico adotado pelo Visconde, não havia, no país, educação cívica, espírito público e condições históricas que favorecessem a descentralização. Bem ao contrário, Uruguai identificava nas províncias "a luta exacerbada das paixões e o predomínio dos interesses de facções sobre os interesses coletivos", como salientou José Murilo de Carvalho (2002, p. 36). De acordo com essa perspectiva, a descentralização levada a cabo no contexto brasileiro significava a concessão de liberdade política aos redutos locais, que deixavam, assim, de serem submetidos eficazmente à mão forte do Estado. A descentralização apontava, em suma, para o exercício de autogoverno - e era convicção de Uruguai que o país não estava preparado para tal experiência.

Após uma década da ação descentralizadora, Uruguai e seus partidários chegaram à conclusão de que o espírito de revolta havia se disseminado e a liberdade teria se 
degenerado em anarquia. No período de descentralização, a seu ver, as assembleias provinciais haviam rompido com a ordem institucional ao legislar contrariamente à Constituição. De modo a defender seus interesses, as assembleias contrariavam os direitos de outras províncias, assim como os tratados nacionais. Isso ocorria principalmente porque, uma vez aprovadas por dois terços dos votos da assembleia provincial, as decisões, mesmo que divergentes de outras esferas de poder, não podiam ser anuladas pela assembleia geral. Isso significava, em outros termos, a prevalência dos interesses locais e particularistas a despeito dos nacionais.

No entendimento do grupo regressista (conjunto de políticos liberais que, tendo apoiado a descentralização, optou pelo retorno à centralização), a melhor solução diante desse quadro sociológico era reservar o acesso ao Estado a uma elite iluminada. Estabelecer-se-ia, assim, como centro de razão da prática política o Estado, em oposição ao polo de paixões e interesses particulares e ao caudilhismo das elites locais. Ao operar a partir do gabinete do Ministério da Justiça a retomada da centralização, Uruguai liderou o movimento regressista quando defendeu a ação enérgica do Estado para contenção dos setores populares, considerados bárbaros, e das elites locais, consideradas de pouco espírito público.

Nesse sentido, a descentralização cedia ao fortalecimento do centro, de onde se procederia a organização política, a unidade de interesses dissonantes, a retomada da ordem civil e, principalmente, a manutenção da unidade nacional. Uruguai estava convicto de que o poder central administrava "melhor as localidades quando estas são ignorantes e semibárbaras e aquele ilustrado; quando aquele é ativo e estas, inertes; quando as mesmas localidades se acham divididas por paixões e parcialidades odientas, que tornam impossível uma administração justa 
e regular". Esse poder caracterizava-se, ainda, pelo distanciamento em relação aos interesses locais. "Então a ação do poder central, que está mais alto e mais longe, que tem mais pejo e é mais imparcial, oferece mais garantias" (Uruguai, 2002, p. 437).

Em outras palavras, o movimento regressista, ao restabelecer politicamente o poder central como eixo da política, pretendia fazer vigorar os interesses do todo sobre as partes, do centro sobre o local e, ainda, do público sobre o privado. Com o centro, pretendia-se recompor o laço de união entre interesses comuns e gerais da sociedade, além de evitar a fragmentação do território. A centralização permitia ao Estado firmar-se como portador dos interesses comuns, mestre da missão civilizadora, assegurador do princípio da liberdade e instrumento de construção da Nação. Essa centralidade do Estado na vida política assegurava, para Uruguai, a unidade territorial e afastava os riscos 208 implícitos na descentralização, sobre os quais questionava: "quem há aí que possa contestar que a continuação desse estado de completa desorganização e anarquia social, à qual davam o nome de liberdade, traria por fim a dissolução do Império?” (Uruguai, 2002, p. 460).

Por certo, esse período constituiu momento de flexão no projeto político liberal importado à época. Ao confrontar-se, no cenário nacional, com o primado da unidade territorial e com a interpretação sociológica de um mundo social adverso à prática da liberdade, o projeto político liberal de parte dos regressistas não negou a liberdade como valor político irremediável. Considerou, porém, mais adequado à realidade local, regulá-la, de modo a direcionar os dirigentes das províncias ao exercício da autoridade com liberdade. Na concepção do Visconde, a liberdade havia de ser "prática, séria e tranquila" ou ainda "sólida, tranquila e duradoura" (Uruguai, 2002, p. 498). Segundo José Murilo de Carvalho (2002), inseriu-se, então, no código genético 
político brasileiro, um compasso saquarema, no sentido de ser conservador, de conciliar liberdade e ordem, princípios de movimento e de conservação.

Embora considerasse a descentralização inadequada à base do mundo social nativo e ao projeto do território nacional, Visconde admitia em seus escritos políticos tocquevilleanos, que a centralização política e administrativa operada no Império oferecia riscos. Entre eles, o de sobrecarregar o governo, do qual todos esperavam tudo. Essa centralidade dificultava a aprendizagem do autogoverno e o desenvolvimento da liberdade. Nesse sentido, para evitar a dependência para com o governo e favorecer o desenvolvimento da liberdade, Uruguai vislumbrava a possibilidade de acomodar a fórmula da centralização política à descentralização administrativa.

De acordo com essa fórmula, cabia ao Estado induzir a descentralização administrativa, aproximando o governo do povo. No entanto, Uruguai considerava que havia países em que “[...] ainda não estão difundidos em todas as classes da sociedade aqueles hábitos de ordem e legalidade, únicos que podem colocar as liberdades públicas fora do alcance das invasões do poder, dos caprichos da multidão e dos botes dos ambiciosos [...]" (Uruguai, 2002, p. 492).

Esses países não eram considerados "devidamente habilitados para o self-government". Por isso, seu projeto era, então, o de "[...] começar a introduzi-lo pouco a pouco, e sujeitar esses ensaios a certa tutela e a certos corretivos". Nesse sentido, o Estado assumia o papel de tutor da organização social e pedagogo da liberdade, isto é, verdadeiro preceptor da sociedade em formação, pois, para Uruguai, "é preciso ir educando o povo, habituando-o, pouco a pouco, a gerir seus negócios” (2002, p. 492). Concebia-se, dessa maneira, a conciliação entre liberdade e ordem.

O projeto tutelar a ser exercido sobre os de baixo visava desenvolver gradualmente o "interesse bem-compreen- 
dido"2 nessas terras tropicais. A obra da civilização tornava-se, então, uma questão pedagógica e educacional a ser implementada pela política, da qual fazia parte mais a contenção do avanço multitudinário do que a auto-organização dos desejos dessa multidão. Dito ainda de outro modo, tratava-se de educar o social pela política, ao mesmo tempo que cabia ao Estado moldar os interesses particulares aos interesses gerais ou comuns.

Como é sabido, o dilema entre centralização e descentralização resultou em uma federação à brasileira - a Primeira República -, na qual o centro, não mais imperial e sim republicano, conservava sua primazia como elemento organizador e civilizador. Visto que a sociologia indicava um substrato social adverso à construção civilizadora, para alguns pensadores dessa época restava fazer desse substrato o objeto da política, em vez de fundamento e origem do poder político. Assim, o projeto de civilização como regula-

210 ção, executado pelo poder constituído sobre o povo, trazia implícita a dissociação originária entre a força política e a força social.

\section{Descentralização política e mercado como eixo estruturante da vida social}

Contraponto ao projeto regressista, a obra de Tavares Bastos professava um liberalismo nascente, que ainda se adequava aos trópicos. Com efeito, enquanto para o regressista Visconde de Uruguai civilizar significava centralizar a política (e descentralizar paulatinamente a administração), para o liberal Tavares Bastos, civilizar traduzia-se por descentralizar mesmo a política. Era nela que Bastos localizava o problema brasileiro, enquanto, para os regressis-

\footnotetext{
${ }^{2}$ Refere-se, aqui, ao uso feito por Tocqueville da noção de "interesse bem-compreendido" para designar práticas como a do associativismo, que entende a promoção do bem-estar individual como reflexo do bem-estar coletivo. A dimensão individual está, assim, incorporada à dimensão coletiva.
} 
tas, a questão estava na formação social dos grupos que habitavam este território.

Para esse americanista, a diversidade étnica não se revelava um obstáculo, pois mais forte do que qualquer conflito dela derivado era "o gosto de liberdade" prevalecente nas Américas. Assim, o liberalismo, aqui, não era mero "acidente, mas uma tradição" (Bastos, 1937, p. 9). Nesses termos, a reflexão sociológica desse autor apontava para a crença de que homens livres eram capazes de um governo livre, bastando, para isso, liberar os apetites da gente brasileira por meio de uma reforma descentralizadora das instituições.

Nessa perspectiva, o tema da anarquia e da dissolução da sociedade aparecia em Bastos não como vício genético, mas sim como efeito do processo de inibição de iniciativas e de abafamento de interesses locais ao qual estavam submetidas as províncias. Na visão do autor, as distinções históricas, geográficas e populacionais existentes entre as províncias, não portavam o germe da dissolução territorial, como parecia aos olhos de Uruguai. O americanista denunciava a centralização como irrealizável na prática: "Quereis apreciar em algarismos o fato de que algumas, pelo menos, das províncias, por sua situação geográfica, apenas se prendem oficialmente ao governo central situado tão longe delas?" (Bastos, 1937, p. 26, grifo do autor). Essa denúncia afirmava, ao mesmo tempo, os princípios americanistas avessos ao modelo monárquico europeu implantado nos trópicos brasileiros. A conclusão era de que os males dessa terra não estavam em seu substrato social, mas na transplantação de um aparato institucional e de uma cultura política ibérica para o continente americano.

Tavares Bastos não estava alheio às dificuldades relativas ao social. "Não desconhecemos o valor de uma péssima educação histórica que, sem preparar os povos para a liberdade, cerca de perigos formidáveis as instituições novas". Não obstante reconhecesse essa dificuldade de 
formação, julgava fundamental fazer avançar a descentralização para além da eleição local dos presidentes de províncias, liberando as iniciativas, os apetites e os interesses individuais, até romper com a tutela do Estado. Ao vislumbrar um futuro americano para o Brasil, combatia a máxima conservadora, segundo a qual "é mau o povo, não pode ser bom o governo", com que os conservadores "atiram para o mundo das utopias as ideias democráticas" (Bastos, 1937, p. 31).

Todavia, o processo de liberação prescrito por Tavares Bastos não tinha ênfase na associação livre dos indivíduos. Essa ênfase recaía sobre a congregação de indivíduos e capitais, as sociedades anônimas e sociedades limitadas. Assim, seus impulsos em prol da democratização dessa parte tropical da América concentravam-se em "remover todos os empecilhos à reunião de capitais e esforços para um fim comum"; "garantir o direito e promover o exercício da ini-

212 ciativa individual, de animar e fortalecer o espírito de associação, de restringir a interferência da autoridade, e conceder a maior liberdade em matéria de comércio e indústria"; além disso, buscava "promover o espírito de empresa e a iniciativa individual” (Bastos, 1937, pp. 175-7).

Desse modo, eram encontrados aí os limites da fé na liberdade e na democracia como natureza do continente americano, pela qual Bastos criticava o centralismo político e afirmava contrariar "os que desejam a eternidade para as constituições e o progresso lento para os povos" (Bastos, 1937, p. 9). Se, por um lado, Bastos enfatizava a necessidade de desenvolver associações de perfil empreendedor, por outro, dedicava pouca atenção ao trabalho escravo e à revisão da estrutura agrária, que acorrentavam os homens a formas de dependência e obstaculizavam a formação de um espírito público.

Nesse sentido, embora reconhecesse que libertar o trabalho do regime de escravidão fosse uma demanda moral, 
defendia que não o fizessem sem antes avaliar os abalos à economia das províncias. Assim, propunha uma mudança planejada, lenta, gradual e segura, com o pagamento de indenizações aos proprietários de escravos, de modo a não impingir prejuízos e crises econômicas às províncias. Bastos não preconizava um projeto de contenção das massas, pedagogia estatal da liberdade e tutela governamental da organização social; no entanto, ele não produziu reflexão densa em que questões sociais, que afligiam e sujeitavam as massas, estivessem em primeiro plano.

No pensamento de Bastos, o mercado funcionava como matriz organizadora das paixões e dos ímpetos que dissolviam a ordem social. Espécie de catalisador das energias individuais, o mercado tinha sentido pedagógico, animador da cultura do indivíduo livre e do progresso material. Essa matriz econômica que colonizava o social surgia como corolário de princípios políticos e religiosos. De acordo com eles, Estado e indivíduo eram concebidos como antitéticos, estando o indivíduo sempre vulnerável à ingerência e coerção do poder estatal. Tratava-se, portanto, de um projeto clássico liberal, em que a livre-iniciativa empreendedora fundamentava a quintessência da emancipação do indivíduo.

Enquanto o mercado era apresentado como eixo estruturante da vida social, o reformismo institucional era apontado como solução para a política. Ao analisar a obra juvenil de Tavares Bastos, mais especificamente Os males do presente e as esperanças do futuro, Vianna (1997) observou que a reforma política proposta por esse americanista não se originava dos de baixo, da sociedade civil e dos movimentos sociais. Para Bastos, embora os segmentos sociais fossem livres porque americanos, eles tinham sido europeizados pela política importada, o que explicava os riscos da anarquia e do caudilhismo local. Uma vez considerada essa "contaminação" do social pela política, a perspectiva do autor reconduzia ao centro da cena política tanto Estado quanto elites, vistos 
como preparados para incorporar o liberalismo e induzir o povo à americanização. Em sua visão, aquela recondução do Estado e das elites seria temporária, até que se revertesse o iberismo produzido pela europeização do social brasileiro.

Mesmo que temporária, é preciso notar, como o faz Werneck Vianna, que o projeto da reforma das instituições pelas elites incorporou elementos do iberismo que criticava, a saber, o valor da unidade nacional e o controle social das classes subalternas. O americanismo "vindo de cima" não era, assim, concebido "como uma ampla reforma sociopolítica, moral e intelectual, menos ainda como um projeto popular", assinalou Vianna. Muito pelo contrário, esse americanismo "consistia na estratégia de estadistas que visavam o futuro do país, inscrevendo-o no movimento civilizatório, impelidos por imperativos racionais e não pela representação de interesses concretos com os quais estivessem articulados" (Vianna, 1997, p. 141).

214 Marcados, assim, pelos paradigmas europeu e norte-americano, nem Uruguai nem Bastos puderam divisar a constituição do povo nesse território, povo esse que permaneceria recôndito no pensamento político brasileiro. Consequentemente, até aquele momento, pensadores e homens de Estado preconizavam uma cisão profunda entre o político e o social, o que moldaria também o desencontro entre liberalismo e democracia no Brasil. No compasso da liberdade com ordem, a política demiúrgica imperava sobre os processos sociológicos, instaurando um Estado Nacional, a despeito de haver ou não um povo.

\section{País inventado pela teoria política, democracia sem dêmos} e o centro na periferia

O imperativo da unidade territorial revelou um Brasil concebido menos como comunidade de indivíduos que como espaço geográfico. Isto é, a prática política no Império, alternada entre homens de inclinação liberal e conserva- 
dora, estabeleceu um Estado-nação mais pelo delineamento de fronteiras que pela formação de corpo social. Assim, como resumiu Euclides da Cunha, chegar-se-ia à república sem coisa pública, falar-se-ia de democracia sem dêmos. Reinterpretada por esse descobridor do Brasil profundo, a façanha da construção da nação operada pelo Império era sintetizada por uma ordem legal constituída em meio a uma geografia fragmentada, cujas fronteiras nacionais, carecendo de divisas naturais, eram fruto da vontade política. "Somos o único caso histórico de uma nacionalidade desenhada por uma teoria política. Vimos, de um salto, da homogeneidade da colônia para o regime constitucional: dos alvarás para as leis" (Cunha, 1999, p. 149).

Essa vontade política ia contra o movimento engendrado no interior das forças sociais ao estabelecer a precedência do político sobre o social. Isso denotava que, "[...] ao entrarmos de improviso na órbita dos nossos destinos, fizemo-lo com um único equilíbrio possível naquela quadra: o equilíbrio dinâmico entre as aspirações populares e as tradições dinásticas”. Esse equilíbrio revelava, aos olhos de Euclides, uma contradição inaudita, pois "equivalia à conciliação entre Progresso e Ordem, ainda não formulada em axioma pelo mais robusto pensador do século" (Cunha, 1999, p. 149).

Euclides sabia, no entanto, que a precedência do político sobre o social decorria tanto da força do artifício político quanto da real não constituição social do povo. Essa constituição tinha sido, nos termos do autor, muito vagarosa, informe, desfavorecida pelo meio físico, pelas circunstâncias e pela própria ação política, de sorte que não se falava em povo, mas em "povoamento rarefeito", em "agrupamentos sem uniformidade de sentimentos e ideais", em formações mestiças resultantes de "raças divergentes em todos os caracteres" (Cunha, 1999, p. 136). É preciso registrar que o autor operou um esforço sociológico para decifrar a for- 
mação dos homens dessa terra, incursionando pelos sertões como quem penetrava o mundo real da formação histórica dos homens brasileiros. Tipos sociais presentes no território foram revelados: o "cabano" grão-paraense, o "balaio" maranhense, o "chimango" cearense, o "cangaceiro" pernambucano e todo o jaguncismo vivente no mundo moderno da República. Dessa incursão, resultou a visão de uma "diátese social" (Cunha, 1999, p. 165) presente na oposição do litoral à hinterlândia, aquele portador do artificialismo iluminado ocidental e esta espaço perdido daqueles tipos sociais, extensão de terra obscura, abandonada e alheia à ordem liberal. Pode-se dizer que a concepção euclideana desdobrava-se a partir de uma démarche antropológica, que formulou a dinâmica dos grupos ou tipos sociais e uma démarche sociológica crítica, que teorizou sobre a ação política do Estado na sociedade. Esses dois momentos-chave se combinaram para formar um paradigma para o pensamen216 to social nativo.

A visão de Euclides promoveu, portanto, uma inflexão no pensamento político brasileiro ao opor artificialismo do litoral e genuinidade do interior. Em sua tentativa de formular categorias teóricas nativas, concebeu que divergências étnicas e históricas eram passíveis de atenuação pela uniformidade mental e moral que podia ser operada pelas crenças católicas supersticiosas, pelo fetichismo indígena e pelo animismo africano. A religião surgia, desse modo, como coordenadora das energias - a exemplo do episódio de Canudos, que o autor testemunhou. Por outro lado, reconhecia que os segmentos sociais, ainda que caracterizados pela coragem pessoal e instinto militar, viviam em situação "semibárbara", que tinha raízes na escravidão. Essa condição era, sem dúvida, adversa à formação de uma sociedade republicana ou democrática. Por não haver um dêmos que pudesse corresponder aos espasmos de democracia, Euclides se viu obrigado a reconhecer 
como providencial a atitude daqueles que prorrogaram o advento da República.

No entanto, esse reconhecimento não subsumia a denúncia do artificialismo político e do problema irresoluto do desenvolvimento social. Nesse aspecto, as críticas eram dirigidas ao Estado, esse demiurgo elaborado pelo cânone ocidental e estranho ao agrupamento social brasileiro. Desse modo, o autor denunciava um aparato político totalmente alheio às necessidades do social, o que denotava que legislar o Brasil gregário de 1823 "era trabalho todo subjetivo, ou capricho de minoria erudita discorrendo dedutivamente sobre alguns preceitos abstratos, alheia ao modo de ser da maioria" (Cunha, 1999, p. 153). Compunha-se, dessa maneira, uma sociedade proteiforme e insolidária, de modo que "a diretriz da nossa história retorcia-se sem uma caracterização precisa, em movimentos parcelados estritamente locais" (Cunha, 1999, p. 136).

Euclides também não aderia ao projeto liberal, no qual via certo artificialismo. Ele divisava nas reformas liberais impostas a "golpe de decreto, à maneira de decisões tirânicas” (Cunha, 1999, p. 154) a realização, aos solavancos, da obra da unidade nacional, sempre despregada de uma base orgânica. Assim, de maneira geral, a invenção política operada em terras brasileiras havia invertido, segundo Euclides, a ordem natural dos fatos, fazendo da unidade territorial, por muito tempo, uma obra frágil. O risco perene de fragmentação do território, que a invenção política buscava obstinadamente evitar, teria consequências peculiares para a invenção de uma formação social. Mas a crítica ao artificialismo político não se esgotava nesses elementos. Ao conceber uma diátese social (litoral e hinterlândia), Euclides formulava a dicotomia entre a minoria europeizada das capitais costeiras e a massa proteiforme do sertão e, desse outro modo, ilustrava o distanciamento entre governo e povo. De acordo com essa perspectiva, "a nossa evolução, 
por ser estritamente política, era problemática. Pelo menos ilusória" (Cunha, 1999, p. 169), pois dependia de uma minoria educada à europeia.

Estava implícito, assim, o descompasso entre avanço político e desenvolvimento social, já que enquanto a minoria europeizada conduzia a evolução política, "o resto [do povo] jazia no ponto em que o largara a metrópole, obscuro e dúbio - amálgama proteiforme de brancos, pretos, amarelos, uns e outros prática e moralmente prejudicados pela escravidão crescente com o tráfico, que se não extinguira” (Cunha, 1999, p. 169). A crítica ao artificialismo litorâneo trazia em si outra visão da dialética entre civilização e barbárie. Mais do que a ideia de que um povo bárbaro devia ser educado pelo Estado, guardião da civilização - uma fabulação à qual aderem os liberais -, encontrava-se a crítica ao distanciamento entre os centros de poder e as forças sociais, ou melhor, ao insulamento do poder prati218 cado à europeia. A falta de correspondência entre governo e povo configurou, com efeito, na concepção de Euclides, um Estado mais moderno que sua sociedade. Mesmo assim, o autor não aderia à precedência daquele sobre esta. Para ele, a inventividade política que legislava o Brasil gregário "[...] seria tudo, menos obedecer à consulta lúcida do meio" (Cunha, 1999, p. 153). Assim, enquanto a política instalava-se estranha, liberal e europeia, o mundo social se compunha de homens ainda formados em bandos étnica e historicamente indistintos.

Euclides dirigiu sua crítica também ao bastião do processo civilizador iluminista, e assim revela uma visão muito aguda e peculiar acerca desse tema. A percepção de que por esse processo, imposto de cima para baixo, "condenávamo-nos à civilização. Ou progredir, ou desaparecer" (Cunha, 1999 , p. 154) permite atribuir ao autor republicano o papel de uma das vozes mais dissonantes do meio progressista de sua época. Isso ocorre porque, a partir de seu olhar, podia- 
-se vislumbrar outro projeto modernizador e alternativo para a periferia do mundo, espaço onde se encontrava uma "geografia de formações sociais estranhas aos códigos hegemônicos da modernidade central” (Maia, 2007, p.84), tais como o individualismo liberal e a organização da sociedade contratual baseada no mercado. Dessa perspectiva, Euclides da Cunha integrou um mapa cognitivo que apresentava o país como parte de um "novo mundo". Não se tratava do mundo especificamente americano, mas um de sociabilidade nova, inventiva e complexa, sem história e tradições profundas. Assim, o autor percebeu que toda a invenção social gerada nesse novo mundo, avesso à modernidade central, não havia sido reconhecida pelas instâncias de poder que, desde o Império até a República de seu tempo, demandavam tradições inexistentes na história do país. De certo modo, entrevia-se nesse pensamento que a novidade deveria partir dos traços nativos, distinta das marcas do projeto iberista ou americanista.

\section{Zonas de confluência entre os ideais democráticos e a formação social}

A projeção de uma civilização distinta daquela produzida pela modernidade central ganhou impulso em obras posteriores a Euclides. A quebra da unidade territorial já não era questão para os intelectuais dos anos de 1930, mas sim a formação de uma república democrática em meio a soluções autoritárias, em choque contra o combalido liberalismo no cenário mundial. Assim, se, por um lado, testemunhava-se o alargamento da participação de camadas populares no sistema eleitoral, por outro, a crítica à representação democrática era patente. Nesse contexto, Buarque de Holanda, em busca de traços da formação social brasileira que confluíssem para um projeto democrático, refundou a crítica a uma teoria política que não tinha como esteio a sociabilidade real. Para ele, a reflexão sobre o ingresso do Brasil no mun- 
do moderno não podia se dar sem a busca pela singularidade da formação social brasileira e, por conseguinte, sem se imaginar uma democracia à brasileira.

Para identificar elementos sociais benfazejos à democracia, Holanda lançou mão da investigação sociológica, o que o levou a afirmar a necessidade de construção de uma sociedade democrática, ou seja, de uma ordem social democrática, mais do que de uma configuração político-institucional. Essa perspectiva, por sua vez, pôs em destaque a construção de uma ética no lugar de uma moral na política. De certo, esse projeto ético almejava conciliar o pensamento sociológico e político, rompendo o paradigma do Estado detentor da razão, em contraste com o povo como portador das paixões. Holanda censurava os políticos que "não duvidaram um único momento de que sã política é filha da moral e da razão. E assim preferiram esquecer a realidade, feia e desconcertante, para 220 se refugiarem no mundo ideal de onde lhes acenavam os doutrinadores do tempo". Desse modo, os políticos, que tendiam a ver a sociedade pelo viés negativo, "criaram asas para não ver o espetáculo detestável que o país lhes oferecia" (Holanda, 1956, p. 275). Assim, o projeto político-ético divisado pelo autor buscava compreender os princípios que motivavam, distorciam, disciplinavam e orientavam o comportamento dos brasileiros. Pretendia incorporar uma reflexão a respeito da essência das normas e valores presentes na realidade social e que execrasse o mundo ideal e a metafísica política dos doutrinadores. De acordo com essa visão ética da política, "as formas superiores da sociedade" deveriam ser "como um contorno congênito a ela e dela inseparável: emergem continuamente das suas necessidades específicas e jamais das escolhas caprichosas" (Holanda, 1956, p. 278).

Atribuir um contorno congênito às instituições políticas da sociedade sugeria a necessidade de emergên- 
cia da soberania popular na democracia brasileira. Era evidente que a busca pelo conteúdo vivo e espontâneo recôndito na realidade social rejeitava toda obra de um Estado espiritual transcendente à ordem natural das coisas. Foi nesse sentido que a desventura do liberalismo foi criticada, vista por ele como "inútil e onerosa superfetação” (Holanda, 1956, p. 278). Esse autor foi muito enfático quanto a elaborações engenhosas, defendendo que as formulações teóricas não se furtassem de se encontrar com a realidade. "Poderemos ensaiar a organização de nossa desordem segundo esquemas sábios e de virtude provada, mas há de restar um mundo de essências mais íntimas que, esse, permanecerá sempre intacto, irredutível e desdenhoso das invenções humanas" (Holanda, 1956, p. 278). Era preciso formular "nosso próprio ritmo espontâneo", "a lei do fluxo e do refluxo”, caso contrário, a produção política reduzir-se-ia a "um compasso mecânico e uma harmonia falsa”.

Havia algo na formação brasileira, segundo o autor, que não se expressava por meio da política, algo furtivo, intacto e íntimo a ser extraído e forjado, de modo a constituir a harmonia desejada. Na tentativa de favorecer essa constituição harmônica, Holanda espreitava um "elemento normativo sólido, inato na alma do povo, ou mesmo implantado pela tirania" (1956, p. 274). Aos seus olhos, a cordialidade não constituía, ainda, o ritmo espontâneo próprio à formação social e capaz de produzir os bons princípios necessários à conformação de um projeto político orgânico e harmônico. Para isso, era necessário identificar "zonas de confluência e de simpatia” entre os ideais democráticos e a formação social. Ainda que entrevisse nesta última uma tendência mais forte à tirania do que à democracia - aqueles eram os anos de 1930 -, essas zonas de confluência podiam ser ativadas. Ele acreditava que a compatibilidade entre os ideais democráticos e a formação social estava, por exemplo, na 
repulsa à hierarquia racional, na qual via a resistência ao fortalecimento de obstáculos postos à autonomia do indivíduo. Da mesma forma, o cosmopolitismo, a capacidade de absorção de influências novas e a "relativa inconsistência de preconceitos de raça e cor" consistiam, para esse autor, em fortes aliados das ideias democrático-liberais (Holanda, 1956, p. 273).

De certo modo, essas observações tendiam mais para uma fértil imaginação sociológica que para uma forma weberiana de conduzir a reflexão (embora esse traço não tivesse desaparecido). Assim, essa reflexão abria-se às conjecturas, como a que imaginava se a cordialidade - vista, em outra passagem, como inviável na produção de bons princípios - poderia, em novas condições políticas, corresponder à noção rousseauniana de bondade natural (Holanda, 1956, p. 274); se o do temperamento nacional se adequaria bem às ideias democráticas gestadas na Revo222 lução Francesa. A identificação de zonas de confluência entre traços da formação social e ideais democráticos revelou, em Holanda, um americanismo nativo avesso ao iberismo, porém distinto do americanismo de importação (mais próximo de Bastos). A seu modo, esse americanismo nativo invocava uma ruptura com a tradição ibérica a qual se daria à medida que o social, por exemplo, se desvinculasse do agrarismo e recriasse, à sua maneira, uma modernidade urbana. Essa maneira própria de ser, inaugurada com a abolição, teria sido "crismada", ilusoriamente, de americana. A favor de um americanismo brasileiro, Sérgio Buarque atribuía o fato de a cultura ser predominantemente ibérica e lusitana, "sobretudo, às insuficiências do 'americanismo', que se resume até agora, em grande parte, numa sorte de exacerbação de manifestações estranhas, de decisões impostas de fora, exteriores à terra" (Holanda, 1956, p. 251). Para ele, a transplantação de aparatos externos, como a do governo lusitano para o Brasil, estabelecia 
o desterro dos brasileiros na própria terra (Holanda, 1956, p. 15). Assim, a crítica aos projetos importados caracterizava seu anti-iberismo e o distinguia do anti-iberismo de tradição americanista.

O "weberianismo" de Holanda se evidencia exatamente na justificativa que este elabora para a ruptura da política nacional com a herança "patriarcal" e "personalista", de sorte a encontrar um caminho para a modernidade. A herança ibérica estava associada a qualidades atrofiadas de ordenação, disciplina e racionalização; ao individualismo derivado de personalismo, avesso a acordos coletivos e iniciativas empreendedoras e aos padrões de sociabilidade inerentes à família e adversos à impessoalidade. Na perspectiva desse autor, a ausência de coesão, o indivíduo infenso a causas coletivas, a incapacidade de organização e a falta de culto ao trabalho denotavam problemas para a construção de uma esfera pública democrática. De modo geral, as instituições implantadas pela cultura ibérica haviam favorecido mais a desagregação do que a união dos homens, na eterna tentativa de conter e refrear as paixões. Essas instituições raramente tinham promovido a associação de forças ativas.

Ainda quanto às diferenças entre a proposta de Holanda e o discurso da tradição liberal e americanista, nota-se que aquela rejeitava a proposta do Estado tutelar, pedagogo e autocrático. Na invocação que o autor fazia de um "contorno congênito" para as instituições, havia a clareza de que o atraso do país não estava em sua sociedade. E, nesse sentido, Holanda considerava a sociedade mais moderna que suas instituições. Ele compreendia que estava em curso uma revolução lenta impulsionada pela sociedade contra os traços ibéricos predominantes no aparelhamento político. Depositava então sua esperança, não no aparelhamento político do Estado, e sim no protagonismo do povo baseado em valores democráticos. 


\section{Elementos democratizantes no interior da sociedade colonial/imperial}

Enquanto Holanda via com bons olhos a ruptura com a tradição ibérica na passagem para o mundo moderno, Gilberto Freyre construía, a partir da perspectiva do iberismo, a proposta de uma sociologia positiva da formação social brasileira. Apesar dessa assimetria, Freyre e Holanda operaram de maneira semelhante ao reconhecer a originalidade da formação social do Brasil. A démarche freyreana estava igualmente centrada no estudo da dinâmica social presente na sociedade brasileira (vida cotidiana, costumes, práticas, arquitetura), deixando de lado a vida institucional-política.

Para Freyre, o elemento português tinha certa genialidade, adaptabilidade e plasticidade, das quais resultaram um inventário culturalmente rico e uma sociedade brasileira original, mestiça e plural. Esse reconhecimento do valor

224 da colonização portuguesa produziu a valorização da formação social brasileira, de seu povo e costumes. Diferentemente de Holanda, para quem o elemento lusitano submetia as outras culturas presentes na sociedade, Freyre considerava que a colonização portuguesa havia criado uma cultura distinta, viva e em movimento, derivada da fusão das diferentes matrizes étnicas. Assim, aos olhos de Freyre, a tradição era benfazeja, plena de positividades.

O fato de valorizar a tradição não significava que Freyre ignorasse o arranjo polar, disposto entre dominadores e dominados (senhores num extremo e escravos noutro) e, inclusive, a presença do "preconceito de branquidade". Todavia, percebia a interpenetração natural entre esses polos, origem de uma cultura mestiça, ou seja, partilhada entre os dois extremos. Sobre isso recaía seu interesse. Ele via essa interpenetração ocorrer também entre dominados e dominadores, homens do litoral e do sertão, e resultar em novas mentalidades, de acordo com as quais se transferiam 
indivíduos ou até famílias inteiras de uma raça para outra, de uma classe para outra.

Além disso, Freyre identificava, nas práticas sociais como o apadrinhamento de filhos ou "crias" de classes e raças diferentes (a figura do pai social) - formas de dissolução contínua do que havia de rígido na estrutura social. De algum modo, ele observava certa mobilidade social no amalgamento entre classes e raças, que funcionavam como espécies de "flutuações sociais e étnicas" ou de "despedaçamento de formas duras, ou menos plásticas", de modo que "até o que havia de mais renitentemente aristocrático na organização patriarcal de família, de economia, e de cultura foi atingido pelo que sempre houve de contagiosamente democrático ou democratizante e até anarquizante" (Freyre, 1951, p. 638). O elemento de democracia da sociedade aparecia, então, nos traços de plasticidade social.

De maneira geral, para Freyre, a formação social brasileira primava por mecanismos de solidariedade e práticas de confraternização que esmaeciam os antagonismos. Assim, para bem e para o mal, o patriarcalismo mal-afamado por Holanda era visto por ele como um sistema de efeitos sociais contraditórios e em que era possível encontrar conteúdo democratizante. Essa possibilidade estava no entrelaçamento entre popular e nobre, plebeidade e fidalguia (Freyre, 1951, p. 710). A sociologia freyreana focava elementos que dissolviam as estruturas inflexíveis no quadro das relações sociais. Assim, onde alguns notavam índices de antagonismo, Freyre buscava encontrar os possíveis vínculos de solidariedade. No lugar de focalizar os distúrbios, ele investigava as formas de conciliação. O quilombo de Palmares, por exemplo, não lhe suscitava nenhuma dissensão presente na sociedade. Embora admitisse que essa havia sido a primeira cidade a se levantar contra os núcleos dos engenhos, antes mesmo da ordem urbana fundada por mercado e Estado, observava naquele espaço de mocambos e de "regime paras- 
socialista" a existência de práticas enaltecedoras de solidariedade e de organização cooperativista. Diferentemente de Holanda, Freyre não chegou a divisar, na sociedade brasileira, a possibilidade de organização social turbulenta e revolucionária, capaz de romper com a ordem político-social imperante e de quebrar as correntes entre dominadores e dominados. Divisava, sim, uma sociedade pacífica, cuja hierarquia patriarcal funcionava como eixo promovedor da harmonia social. Dessa forma, os valores de harmonia e solidariedade se confundiam com a dinâmica democrática que Freyre via engendrar-se na sociedade.

Portanto percebe-se que, para Freyre - em oposição a Uruguai e diferentemente de Euclides -, esteve em curso, na sociedade brasileira, nos séculos XVIII e XIX, uma formação social de certo modo consistente e homogênea, que se produzia independentemente da ação do Estado. De acordo com essa concepção, a imagem dessa socieda226 de como amontoado de bárbaros sem ordem possível ou como composição social heterogênea e proteiforme cedia lugar a uma sociedade de viços orgânicos e harmônicos, que tendia a dar existência a um corpo social e a relações democráticas. Ao identificar um andamento democrático produzido no seio da sociedade em ritmo e compasso próprios, Freyre apresentava restrições quanto à entrada do país no mundo moderno central. Essas restrições remetiam à crítica euclideana, que via no modelo da civilização moderna a imposição de um padrão por países centrais. Elas remetiam também ao questionamento de importação de projetos, por Holanda, ilustrado por aquilo que chamou de sensação de desterro na própria terra. Freyre, no entanto, tinha apreço pela singularidade brasileira justamente porque julgava que ela havia sido plasmada durante o sistema colonial - e não depois de acabado esse período.

Os elementos de dissensão e antagonismo que perturbaram a marcha própria à organização brasileira teriam 
sido introduzidos, na visão de Freyre, com o advento do moderno, cujo marco inicial teria sido a vinda da família real ao Brasil, em 1808. Ela significou, a seus olhos, o advento indesejado da modernização ocidentalista, individualista e burguesa (Souza, 2003). Freyre acreditava que a transição da sociabilidade rural e agrária para a urbana e moderna assinalava o declínio da ordem patriarcal e, por conseguinte, a dissolução da cultura mestiça em prol de uma cultura de imitação de valores e estilos de vida europeus. Com o recrudescimento da modernização e a substituição do complexo "casa grande e senzala" pelo complexo "sobrado e mucambo", reforçavam-se distâncias sociais e culturais, exacerbavam-se antagonismos raciais e sociais.

Freyre sugeriu que a matriz ocidentalista e burguesa teria sido adversa ao patrimônio sociológico brasileiro. Assim, o advento da modernização instaurava a instabilidade e a desagregação social. Artes e hábitos mestiços, por exemplo, "que já se haviam tornado artes e hábitos da raça, da classe e da região aristocrática" voltavam a ser segregados como "artes e hábitos de classes, raças e regiões consideradas inferiores ou plebeias” (Freyre, 1951, p. 699). Os modos particularistas e individualistas atribuídos aos brasileiros teriam sido desenvolvidos, na verdade, a partir do aniquilamento da organização social colonial e em detrimento das práticas coletivistas. Freyre não acreditava que a gente desta terra tivesse adotado espontaneamente tais atitudes morais e padrões de vida novos. As críticas ao padrão ocidental de modernidade, no entanto, não significavam negação do moderno. Sendo o advento moderno implacável, o autor conformava-se em ressentir a perda da singularidade social brasileira, cujo legado era ameaçado e submetido, por sua vez, ao avanço da europeização. Ressentia-se precisamente da perda do elemento dissolvente, não antagonista e democratizante que dava à cultura sua maneira própria, maneira essa que, segundo Rezende de Carvalho (2002), 
pode ser lida como uma solução processualista, a "solução brasileira". Tal solução significava, nos termos dessa autora, a adoção do passado como balizador do futuro, e, por conseguinte, a configuração de um projeto de modernização pacífica sem ruptura com a tradição.

Contudo, essa conformação vinha acompanhada da crença de que a plasticidade própria àquela sociedade absorveria os novos valores induzidos de fora para dentro. Ao observar tal plasticidade como qualidade, Freyre sustentava a esperança na possibilidade de que fossem resguardadas as formas de um assentamento moderno próprio. Essa consistia na forma propriamente brasileira de passar para a modernidade evitando o desfiguramento do inventário social rico em práticas e afetividades. De acordo com Rezende de Carvalho (2002), visto sob esse ângulo, o pensamento freyreano, tantas vezes atacado por defender o baluarte de uma Ibéria antimoderna ou de um progressivismo liberal, pode ser redimido.

Por certo, o pensamento freyreano, como o de nenhum outro grande autor, não esteve imune a tensões. Pode-se dizer que a ausência, em seu aparato intelectual, de uma sociologia do poder figura, em grande medida, como causa das tensões atribuídas ao pensador. Entre elas, a concomitante manutenção da estrutura aristocrática e valorização do conteúdo popular não deixou de ecoar, como apontou Rezende de Carvalho (2002), na fórmula paradoxal da mudança com conservação. Por consequência, teve-se dificuldade de apontar claramente, em Freyre, o alcance das tendências democratizantes da sociedade, isto é, a possibilidade de substituição da ordem patriarcal por outra menos hierárquica e mais igualitária. Tudo se passa como se, para Freyre, o patriarcalismo se apresentasse como matriz eficiente de organização das paixões, aquelas que tanto perturbavam os projetos de civilização concebidos por Visconde de Uruguai. 
Em pouco mais de um século de interpretações sobre o Brasil, de Visconde de Uruguai a Gilberto Freyre, alguns marcos da abordagem sobre o país - como as dicotomias iberismo e americanismo, centralização e descentralização, moderno e periferia, Estado e sociedade - podem ser destacados. No enfoque aplicado aqui ao problema da constituição social e política da civilização brasileira, tais antinomias só interessaram à medida que revelavam as premissas de construção de um pensamento democrático para o país. Como se notou, não há, por parte delas, resposta padrão quanto à questão democrática.

No percurso intelectual do Império à República, política e sociologia impuseram suas pautas para a teoria democrática nativa. Do ponto de vista da precedência política, herdou-se a concepção de que a política educava o social. Para os pensadores que consideravam problemático o substrato social, o Estado (para o Visconde de Uruguai) ou o mercado (para Tavares Bastos) definiam-se como centro da razão em oposição às paixões do povo e, em torno desses elementos, organizavam-se as energias. Assim, um artificialismo político pautado por certo "realismo sociológico" instaurou-se. Do ponto de vista da precedência sociológica legou-se a percepção de que o social deveria guiar a política. Como orientação normativa, defendia-se que um conteúdo social orgânico deveria dar forma a um novo mundo (segundo Euclides da Cunha); ou seja, um projeto ético e um contorno congênito deveriam ser incorporados pelas instituições (segundo Buarque de Holanda) e um inventário social rico daria passagem a relações sociais democratizantes.

Percebeu-se, neste artigo, a relação entre saber sociológico e saber político, no pensamento brasileiro. Com efeito, por muito tempo a sociologia brasileira viveu o drama de se constituir como uma sociologia da "falta", isto é, da ausência de caracteres que se encaixassem em uma obra política. 
E mesmo aquelas interpretações capazes de delinear algo além da falta, como as de Cunha e Holanda, não conseguiram se desvencilhar por completo dessa marca de nascença, à medida que aplicaram suas energias na réplica a tais concepções. Mesmo quando renegaram tal sociologia, tiveram dificuldades para se compor como projeto político e deixaram para seus epígonos a pauta para nova invenção social e política compatível com a democracia.

Em um plano geral, pode-se dizer que a política de vocação territorial, que garantiu dimensões continentais ao país, trouxe consequências marcantes para a formação social. Se, por um lado, instalou a ferro e fogo o Estado-nação, por outro impôs andamento contido de democratização à sociedade. Em decorrência disso, o tema da revolução evocado por Holanda esmaeceu em face do transformismo processualista de Freyre. A fórmula da marcha lenta e gradual retomou o princípio saquarema, segundo 230 o qual a conservação freava e ordenava o ímpeto de movimento irregular.

Assim, o realismo sociológico do qual Uruguai reclamava não cessou de formular uma constituição social avessa a toda forma de autonomia popular, ao exercício de autogoverno e à experiência democrática. Essa concepção sociológica habitou grande parte das vertentes conservadoras e liberais e revelava não só o desencontro entre liberalismo e democracia, como também as premissas de construção de um pensamento democrático no país. O pensamento liberal engendrado ainda no Império deixou intocadas algumas chagas sociais, no afã por promover a emancipação do indivíduo, sua liberdade e livre-iniciativa.

Pergunta-se, ao fim desse percurso: teria a massa indistinta e bárbara, proteiforme e gregária ganhado a consistência e a identidade almejadas para a realização da democracia em terras brasileiras? De outra forma, pergunta-se: teria a democracia, formulada pela modernidade 
central, se moldado à singularidade social, ou, ao contrário, aniquilado o inventário social? São algumas das questões suscitadas pelos autores que serviram de base para a compreensão do Brasil.

Certamente que a feição do povo enquanto constituição social esteve recôndita por longo tempo no pensamento político e social brasileiro, configurando efetivamente uma cisão entre o social (visto como uma incógnita heterogênea) e o político (visto como agente demiurgo). Assim, se o povo constituiu uma questão em si para teóricos, historiadores, sociólogos e atores políticos modernos (Rosenberg, 1986), verdadeira figura do tempo e senhor inapreensível, como escreveu Rosanvallon (1998), algo semelhante ocorreu para os pensadores das sociedades não centrais. Com efeito, a procura euclideana do dêmos ganhou outras tônicas, nos trabalhos de Nelson Werneck Sodré (1963), com a figura do povo-massa; de Maria Sylvia de Carvalho Franco (1969), com a representação dos homens livres dependentes e de Jessé de Souza (2003), com a imagem da ralé estrutural. Não obstante Euclides já inspirasse a busca pela maneira própria de ser moderno, foi com dificuldade que a literatura contemporânea tentou se livrar do espectro da modernidade central.

\section{Thais Florencio de Aguiar}

é doutoranda em ciência política no Iesp-Uerj.

\section{Referências bibliográficas}

BASTOS, A. T. 1937. A província. São Paulo: Companhia Editora Nacional. CARVALHO, J. M. 2002. "Introdução". In: URUGUAI, V. Visconde do Uruguai. São Paulo: Editora 34, pp.11-47.

CARVALHO, M. A. R. 2002. "Casa grande \& senzala e o pensamento social brasileiro”. In: FREYRE, G. Casa grande E̋ senzala: edição crítica. Madrid: Allca XX, pp.887-908.

CUNHA, E. 1999. "Da independência à república”. In: À margem da história. São Paulo: Martins Fontes, pp.133-97. 
FRANCO, M. S. C. 1969. Homens livres na ordem escravocrata. São Paulo: Ed. da Unesp.

FREYRE, G. 1951. Sobrados e mucambos. Rio de Janeiro: José Olympio.

HOLANDA, S. B. 1956. Raizes do Brasil. Rio de Janeiro: José Olympio.

MAIA, J. M. E. 2007. "Espaço e pensamento brasileiro: a Rússia americana nos escritos de Euclides da Cunha e Vicente Licínio Cardoso”. Dados, v.50, n.1, pp.83-115.

ROSANVALLON, P. 1998. Le peuple introuvable: histoire de la répresentation démocratique en France. Paris: Gallimard.

ROSENBERG, A. 1986. Democracia e socialismo: história política dos últimos cento e cinquenta anos (1789-1937). São Paulo: Global.

SODRÉ, N. W. 1963. Quem é o povo no Brasil? Rio de Janeiro: Civilização Brasileira.

SOUZA, J. 2003. A construção social da subcidadania. Belo Horizonte: Ed. da UFMG.

URUGUAI, V. 2002. Visconde do Uruguai. São Paulo: Editora 34.

VIANNA, L. 1997. A revolução passiva: iberismo e americanismo no Brasil. Rio de Janeiro: Revan. 


\section{TÓPICOS PARA UMA REFLEXÃO DEMOCRÁTICA EM UMA CIVILIZAÇÃO TROPICAL}

\section{THAIS FLORENCIO DE AGUIAR}

Resumo: Este ensaio buscou conceber em que medida o pensamento político e social brasileiro, ao interrogar as possibilidades de constituição de uma civilização brasileira, legou tópicos e subsídios para o pensamento sobre democracia nesse território. Esses subsídios foram derivados dos marcos de interpretação sobre o Brasil, como tradição e ruptura, iberismo e americanismo, centralização e descentralização 
ou precedência do Estado e autonomia da sociedade. Para articular esses temas à reflexão sobre democracia, foram analisadas obras de Visconde de Uruguai, de Tavares Bastos, Euclides da Cunha, Sérgio Buarque de Holanda e Gilberto Freyre, produzidas do Império à República. Observou-se, ainda, como a ciência política e a análise sociológica preconizaram uma ação demiúrgica do Estado sobre o social e produziram um entendimento acerca da sociabilidade.

Palavras-chave: Pensamento Social Brasileiro; Pensamento Político Brasileiro, Civilização Brasileira, Democracia, Liberalismo.

\section{TOPICS FOR A DEMOCRATIC THINKING IN A TROPICAL CIVILIZATION}

Abstract: This essay tries to understand to what extent the Brazilian political and social thought, while questioning possibilities of setting up a Brazilian civilization, has left some topics to consider a democracy in Brazil. These topics were derived from different kinds of interpretations about the country, sustained in dualities such as tradition and rupture, iberianism and americanism, centralization and decentralization, State control and social autonomy. In order to link these subjects to understand the characteristics of a democratic thinking, we have analyzed the works written from the Empire to Republic by Visconde do Uruguai, Tavares Bastos, Euclides da Cunha, Sérgio Buarque de Holanda and Gilberto Freyre. Futhermore, we have remarked how political science and sociological analysis advocated a demiurgical action of the State on society and developed a sort of understanding about sociability.

Keywords: Brazilian Social Thought; Brazilian Political Thought; Brazilian Civilization, Democracy, Liberalism.

Recebido: 10/10/2011 Aprovado: 29/08/2012 